Widodo et al., Afr., J. Infect. Dis. (2018) 12(S): 36-43

https://doi.org/10.2101/Ajid.v12i1S.4

\title{
ANTIVIRAL ACTIVITY OF Justicia gendarussa Burm.f. LEAVES AGAINST HIV-INFECTED MT-4
} CELLS

\author{
Agustinus Widodo $^{1^{*}}$, Prihartini Widiyanti ${ }^{2,3}$, Bambang Prajogo ${ }^{4}$
}

${ }^{1}$ Department of Pharmacy, Faculty of Mathematics and Natural Sciences, Tadulako University, Palu, Indonesia; ${ }^{2}$ Faculty of Science and Technology, Airlangga University, Surabaya, Indonesia; ${ }^{3}$ Intitute of Tropical Disease (ITD), Airlangga University, Surabaya, Indonesia; ${ }^{4}$ Department of Pharmacognosy, Faculty of Pharmacy, Airlangga University, Surabaya, Indonesia

*Corresponding Author E-mail: widodoagustinus@yahoo.com

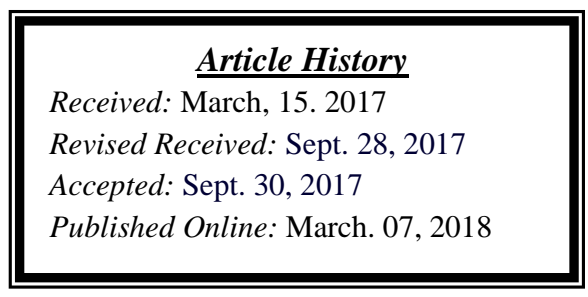

Abstract

Backgrounds: Justicia gendarussa Burm.f. has been known to have anti-HIV activity. This study was conducted to evaluate the effect of incubation time on the antiviral activity of the J. gendarussa leaves extract on HIV-infected MT-4 cells in vitro. Molecular docking test was also conducted to determine the interaction of alkaloids and flavonoids on the $J$. gendarussa leaves against HIV-1 reverse transcriptase receptor. It is expected that this research will provide scientific information on the development of $J$. gendarussa leaves as an anti-HIV drug.

Materials and Methods: In the activity test, the effect of incubation time on the antiviral activity of J. gendarussa leaves on HIV-infected MT-4 cells were evaluated. During the activity test, a parameter of cytolysis effect inhibition on MT-4 cell line was observed after 4 days and 6 days incubation period. The molecular docking test is performed by using Molegro Virtual Docker software to determine the interaction of alkaloid and flavonoid compounds of $J$. gendarussa leaves with HIV-1 reverse transcriptase receptor.

Results: The incubation time influences the $\mathrm{CC}_{50}$ and $\mathrm{EC}_{50}$ value. Fractionated-70\% ethanol extract of J. gendarussa leaves showed a higher anti-HIV activity with $\mathrm{EC}_{50}=3.045 \times 10^{-9} \mu \mathrm{g} / \mathrm{mL}, \mathrm{SI}=6.309 \times 10^{12}$ (4 days of incubation) and $\mathrm{EC}_{50}=6.066 \mu \mathrm{g} / \mathrm{mL}, \mathrm{SI}=58494.845$ (6 days of incubation). From molecular docking test, it was found that flavonoid of $J$. gendarussa leaves could inhibit the activity of HIV reverse transcriptase enzyme.

Conclusion: Fractionated-70\% ethanol extract of $J$. gendarussa has potential as an anti-HIV.

Keywords: Justicia gendarussa, HIV, MT-4 cell, Antiviral

\section{Introduction}

Human Immunodeficiency Virus (HIV) is a retrovirus that infects the human immune system. HIV damages the human immune system by destroying T lymphocyte cell (a type of leukocyte). On the T lymphocyte cell surface, there is cluster of differentiation 4(CD4) receptor. When a number of T-CD4 lymphocyte cells are low then a person more susceptible to be infected (Pattman et al., 2005). The immune system will break down slowly over the increasing number of viruses (viral load) in the body (Naif, 2013). The final stage of HIV infection is AIDS, a condition when CD4 level decrease to very low level (typically $<200$ cells $/ \mathrm{mm}^{3}$ ). This causes ability of the immune system against certain infections seriously impaired (Pattman et al., 2005).

One strategy for HIV-AIDS treatment is antiretroviral therapy (ARV). The anti-retroviral therapy is used to disrupt the life cycle of HIV. This therapy is effective for stabilizing viral load in the blood for a long enough time. But the anti-retroviral therapy also has many side effects that could affect various organ systems (Luma et al., 2012). The side effect could cause drug resistance and worsen the condition in patients. Therefore, new anti-HIV drugs need to be developed through the discovery of new anti-HIV drugs that are more selective and have low toxicity.

The development of anti-HIV drugs could be performed through the traditional medicine research program both flora and fauna. Traditional medicine research is directed to find scientific evidence on the traditional medicine. Currently, there is one plant that is being developed as anti-HIV, namely Justicia gendarussa Burm.f. (Acanthaceae).

$J$. gendarussa is often used as a traditional medicine. Root and leaves of J. gendarussa are usually used as a traditional medicine (Suryowinoto and Pudjoarinto, 1985). 
The results of in vitro test showed that $70 \%$ ethanol extract, fractionated-70\% ethanol extract and water extract of $J$. gendarussa leaves have activity in inhibiting HIV reverse transcriptase enzyme (Woradulayapinij et al., 2005; Prajogo et al., 2016). Current research on J. gendarussa leaves extract on MOLT-4 cell cultures infected with HIV showed that $J$. gendarussa leaves could inhibit HIV replication by decreasing the number of p24 and inhibition of syncytia formation (Widiyanti et al., 2016).

J. gendarussa leaves contain substituted aromatic amine (Chakravarty et al., 1982), flavonoid glycoside i.e. gendarusin A and gendarusin B (Prajogo, 2009), and justidrusamida alkaloids A, B, C and D (Kiren et al., 2014). The main component of the $70 \%$ ethanol extract is apigenin flavonoid glycoside called Gendarusin A (Prajogo, 2014). Flavonoid compounds are known as an anti-HIV natural source of therapy for patients with AIDS by inhibiting HIV reverse transcriptase (Veljkovic et al., 2007; Ko et al., 2009).

In connection with the evaluation of traditional medicine as an anti-HIV, established guidelines of the World Health Organization (WHO) suggest for doing an in vitro test to detect activity and determine the toxicity potential of the traditional medicine. In vitro test is the first step to identify potential compounds with anti-HIV activity. If the activity is greater than its toxicity, then the traditional medicine can proceed to the next test phase. The next step is confirmation of antiviral activity and toxicity in various cell systems (Organization, 1989).

In this study, the anti-HIV activity of J. gendarussa leaves extracts on MT-4 cells was tested. MT-4 cells were selected since the cells are particularly vulnerable to the cytopathic effects of HIV. So the cells are often used in cytotoxicity and antiviral activity test (Kimura et al., 1999). Extract of J. gendarussa leaves used $70 \%$ ethanol extract, and fractionated-70\% ethanol extract (free alkaloids), and water extract. Selection of the extract type is based on several previous studies, where use $70 \%$ ethanol extract of $J$. gendarussa leaves and water extract of J. gendarussa leaves showed potent activity as an anti-HIV (Woradulayapinij et al., 2005; Prajogo et al., 2016; Widiyanti et al., 2016).

\section{Materials and Methods \\ Plant Materials and Extraction Procedure}

Leaves of $J$. gendarussa were obtained from a cultivated crop in Pacet, Mojokerto, East Java province, Indonesia. This plant was identified by the Department of Pharmacognosy and Phytochemistry, Faculty of Pharmacy, Airlangga University under the voucher number 18/H3.1.5/DT/2012. Simplicia powder of J. gendarussa leaves was divided into two groups: acidified leaves powder to release alkaloids and non-acidified leaves powder. Both the powder was extracted using $70 \%$ ethanol for $3 \times 24$ hours in a macerator device, and then the resulting filtrate were concentrated using a rotary evaporator. The extract is dried at $50^{\circ} \mathrm{C}$ a temperature of to obtain a $70 \%$ ethanol extract $(17.4 \% \mathrm{w} / \mathrm{w})$ and fractionated-70\% ethanol extract $(6.4 \% \mathrm{w} / \mathrm{w})$ of $J$. gendarussa leaves. Water extract of leaves of J. gendarussa is made by blending fresh $J$. gendarussa leaves in cold water. Then the resulted filtrate was collected and was dried using the freeze-dry method to obtain water extracts $(1.8 \% \mathrm{w} / \mathrm{w})$ of $J$. gendarussa leaves.

\section{Alkaloid and Flavonoid Screening of J. gendarussa Leaves Extract}

Alkaloid screening of $70 \%$ ethanol extract, fractionated-70\% ethanol extract and water extract of $J$. gendarussa leaves be performed using a TLC GF254 plate with mobile phase chloroform: methanol (9:1). Here, Dragendorf reagent is used to reveal stains. Results test is said to be alkaloid positive if there are orange stains.

Flavonoid screening of $70 \%$ ethanol extract, fractionated-70\% ethanol extract and water extract of $J$. gendarussa leaves be performed by using the immobile phase of TLC GF254 with a mobile phase of butanol: glacial acetic acid: water (4:1:5). Here, borate citric is used to reveal stains. Results test is said to be flavonoid acid if there are yellow-green fluorescence stains using UV $366 \mathrm{~nm}$ (Indonesia, 2008).

\section{Reagents and Chemicals}

Zidovudine-Lamivudine (ZDV/3TC) $\left(\right.$ Duviral $\left.^{\circledR}\right), 2 \mu \mathrm{m}$ nitrocellulose membrane filter (Whatman), sterile water for injection, and aquadest were obtained from CRS-EIRD, Institute of Tropical Disease, Surabaya, Indonesia. RPMI-1640 medium and Fetal Bovine Serum (FBS) were purchased from Gibco. Natrium bicarbonate and $70 \%$ ethanol pharmaceutical grade were purchased from Merck. WST-1 was purchased from Roche. Dimethyl sulfoxide (DMSO) was purchased from Sigma.

\section{Cells and Viruses}

The MT-4 cells (human T-cell leukemia line) were obtained from the Institute of Tropical Disease (ITD) laboratory, Airlangga University, Surabaya, Indonesia. MT-4 cells were cultured in RPMI-1640 media and were equipped with $10 \%$ FBS. The MT-4 cells were maintained in $\mathrm{T}_{25} \mathrm{CCF}$ at $37{ }^{\circ} \mathrm{C}$ temperature in a $5 \% \mathrm{CO}_{2}$ incubator. HIV isolates from a seropositive HIV donor that labeled IDU-18 obtained from ITD laboratory, Airlangga University, Surabaya, Indonesia. HIV cultured on the MT-4 cell in RPMI-1640 medium completed with FBS 10\%. MT-4/HIV cell kept in $\mathrm{CCF} \mathrm{T}_{25}$ at $37^{\circ} \mathrm{C}$ in $\mathrm{CO}_{2} 5 \%$ incubator. 


\section{Cytotoxicity Test}

The cytotoxicity test was performed by a colorimetric method using WST-1 (Kangro and Mahy, 1996; Zhang et al., 2012). $50 \mu 1$ MT-4 cells in a 96-well microplate $\left(2 \times 10^{5}\right.$ cells/well) in the absence or presence of various concentrations of $J$. gendarussa leaves extracts were incubated for 4 days and 6 days at $37^{\circ} \mathrm{C}$ temperatures in a $5 \% \mathrm{CO}_{2}$

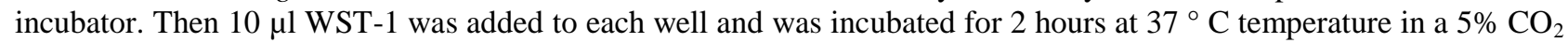
incubator. ZDV/3TC was used as a positive control. The absorbance was measured at $450 \mathrm{~nm}$ wavelength using a microplate absorbance reader.

\section{Cytolysis Effect Inhibitory Test}

The cytolysis effect inhibitory test was performed by a colorimetric method using WST-1 (Kangro and Mahy, 1996; Zhang et al., 2012). MT-4 cells ( 2 x $10^{5}$ cells/well) were infected with HIV in the absence or presence of various concentrations of $J$. gendarussa leaves extracts were incubated for 4 days and 6 days at $37^{\circ} \mathrm{C}$ temperatures in a $5 \% \mathrm{CO}_{2}$ incubator. Then $10 \mu \mathrm{lWST}-1$ was added to each well and was incubated for 2 hours at a $37^{\circ} \mathrm{C}$ temperature in a $5 \% \mathrm{CO}_{2}$ incubator. ZDV/3TC was used as a positive control. The absorbance was measured at $450 \mathrm{~nm}$ wavelength using a microplate absorbance reader.

\section{Statistical Analysis}

Data is analyzed by probit regression analysis using the Minitab version 17 software. Probit regression analysis is used to determine $50 \%$ Cytotoxicity Concentration $\left(\mathrm{CC}_{50}\right)$, which is a concentration that able to decrease $50 \%$ of cell viability.

\section{Molecular Docking Test}

The molecular docking test is performed to determine the interaction of an alkaloid and flavonoid compounds of $J$. gendarussa leaves with HIV-1 reverse transcriptase receptor. The structure of the alkaloid and flavonoid compound is determined by ChemBioOffice Ultra version 12.0 software. The structure of the HIV-1 reverse transcriptase receptor is obtained from Protein Data Bank (http://www.pdb.org/pdb/home/home.do) with 3V4I code. Molecular docking analysis is performed by using Molegro Virtual Docker (MVD) version 5.0 software. From molecular docking test, it obtains the rerank score. Then the rerank score is used as activity prediction.

\section{Results}

TLC performed the alkaloid screening (Table 1). It was found that some oranges stain in $70 \%$ ethanol extract and water extract of $J$. gendarussa leaves. It indicates that in both the extracts contain alkaloids. From the flavonoid screening result, it was found that greenish yellow fluorescence stain in $70 \%$ ethanol extract, fractionated-70\% ethanol extract, and water extract of $J$. gendarussa leaves. It indicates that the three extracts contain flavonoids.

Table 1: Alkaloid and flavonoid screening of the J. gendarussa leaves extract

\begin{tabular}{lcc}
\hline \multirow{2}{*}{ Extract } & \multicolumn{2}{c}{ Test } \\
\cline { 2 - 3 } & Alkaloid & Flavonoid \\
\hline 70\% ethanol extract & + & + \\
fractionated-70\% ethanol extract & - & + \\
water extract & + & + \\
\hline (+) Detected; (-) Not Detected & \multicolumn{2}{l}{}
\end{tabular}




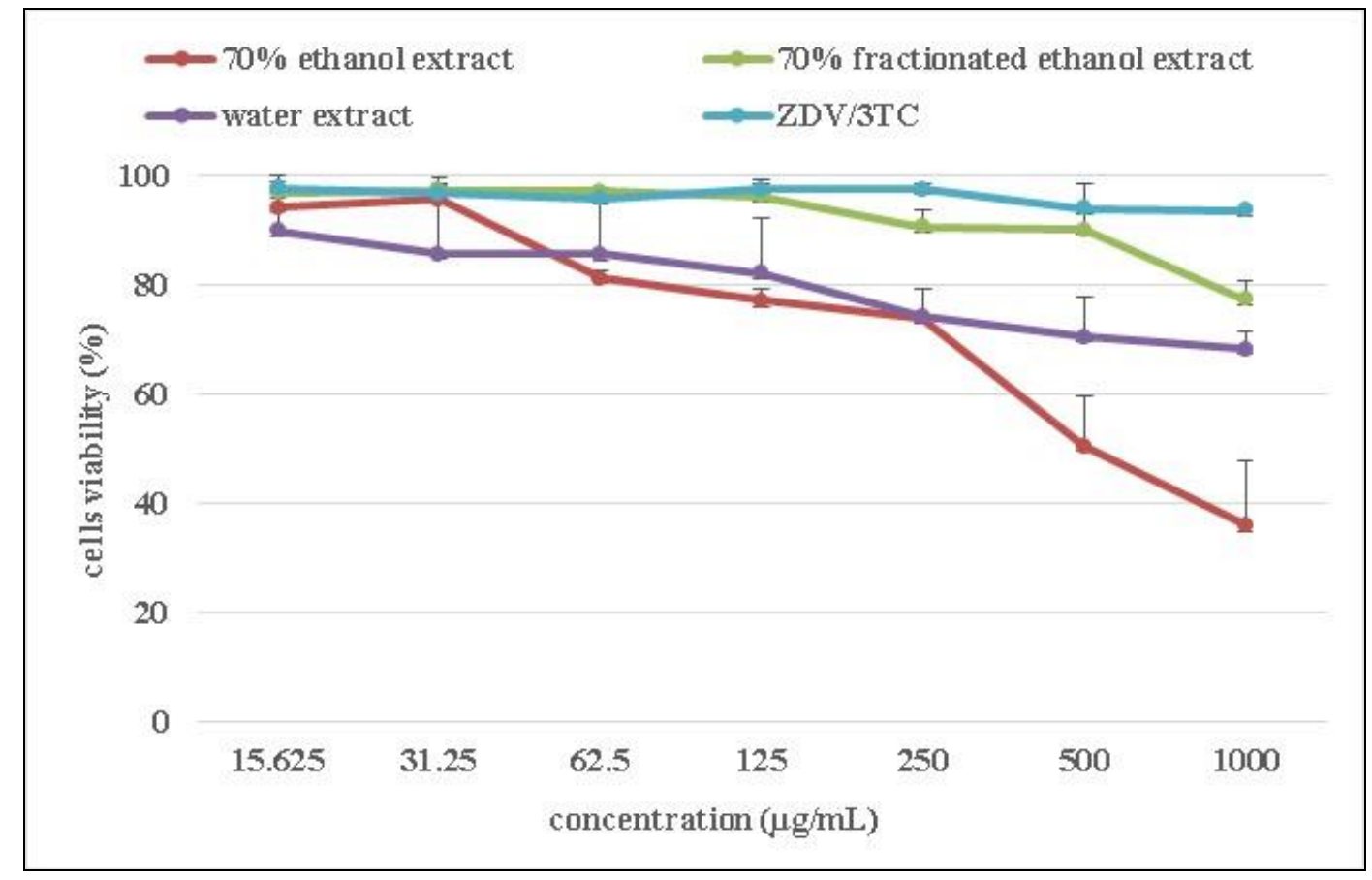

Figure 1: Effect of extracts of $J$. gendarussa leaves and ZDV/3TC on the viability of MT-4 cells after 4 days incubation period.

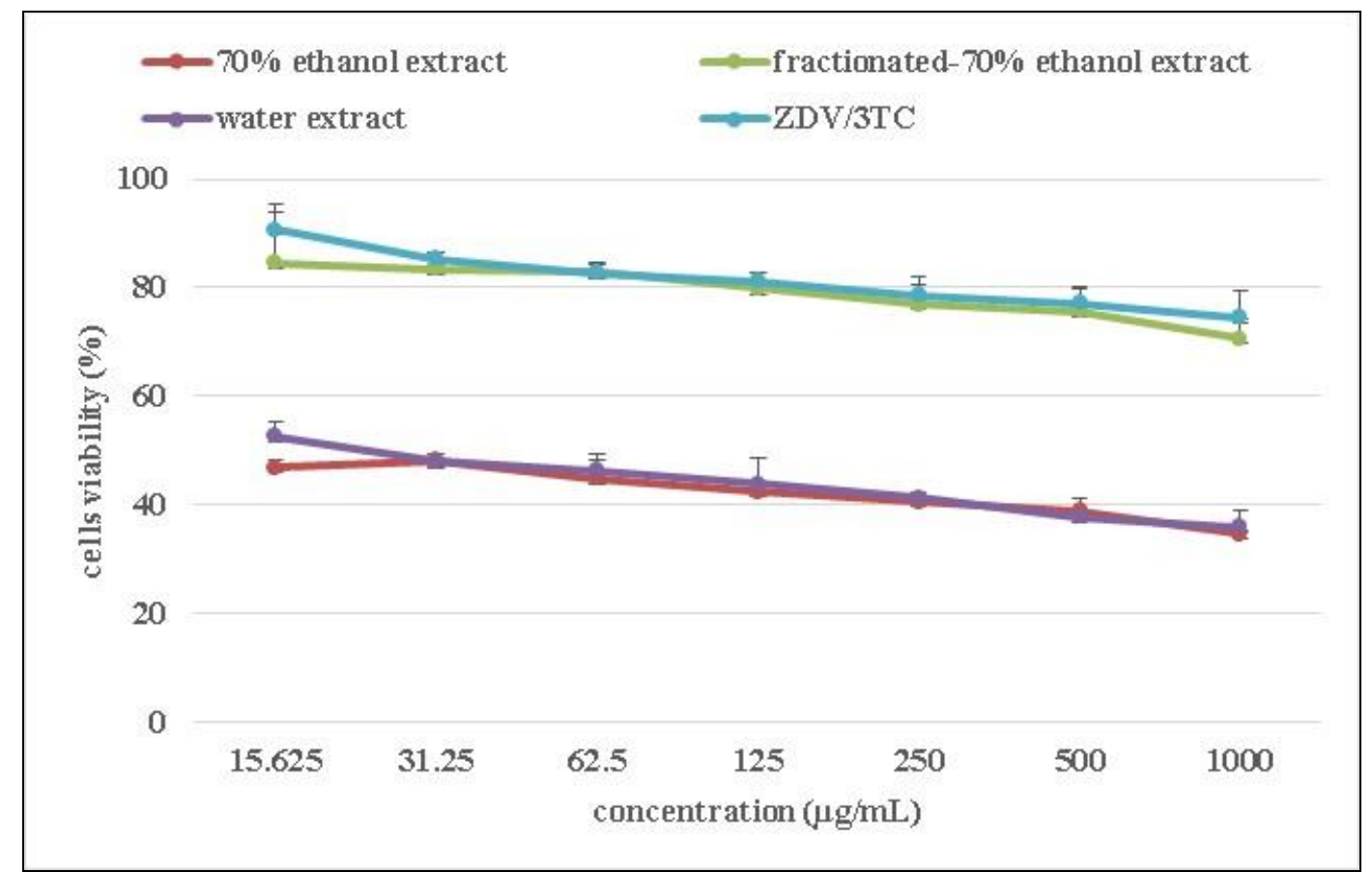

Figure 2: Effect of extracts of J. gendarussa leaves and ZDV/3TC on the viability of MT-4 cells after 6 days incubation period.

From the cytotoxicity test, it was found that incubation period affects cytotoxicity of $J$. gendarussa leaves extract in MT-4 cells. Increasing concentrations extracts of J. gendarussa leaves could reduce MT-4 cells viability. The viability of MT-4 cells after 4 days incubation period and 6 days incubation period were shown in Figure 1 and Figure 2 respectively. The value of cell viability was used to determine $50 \%$ cytotoxicity concentration $\left(\mathrm{CC}_{50}\right)$ value for each test material. Probit regression analysis has calculated the value of $\mathrm{CC}_{50}$. The probit regression analysis was performed by using Minitab software. The $\mathrm{CC}_{50}$ value was presented in Table 2 . 


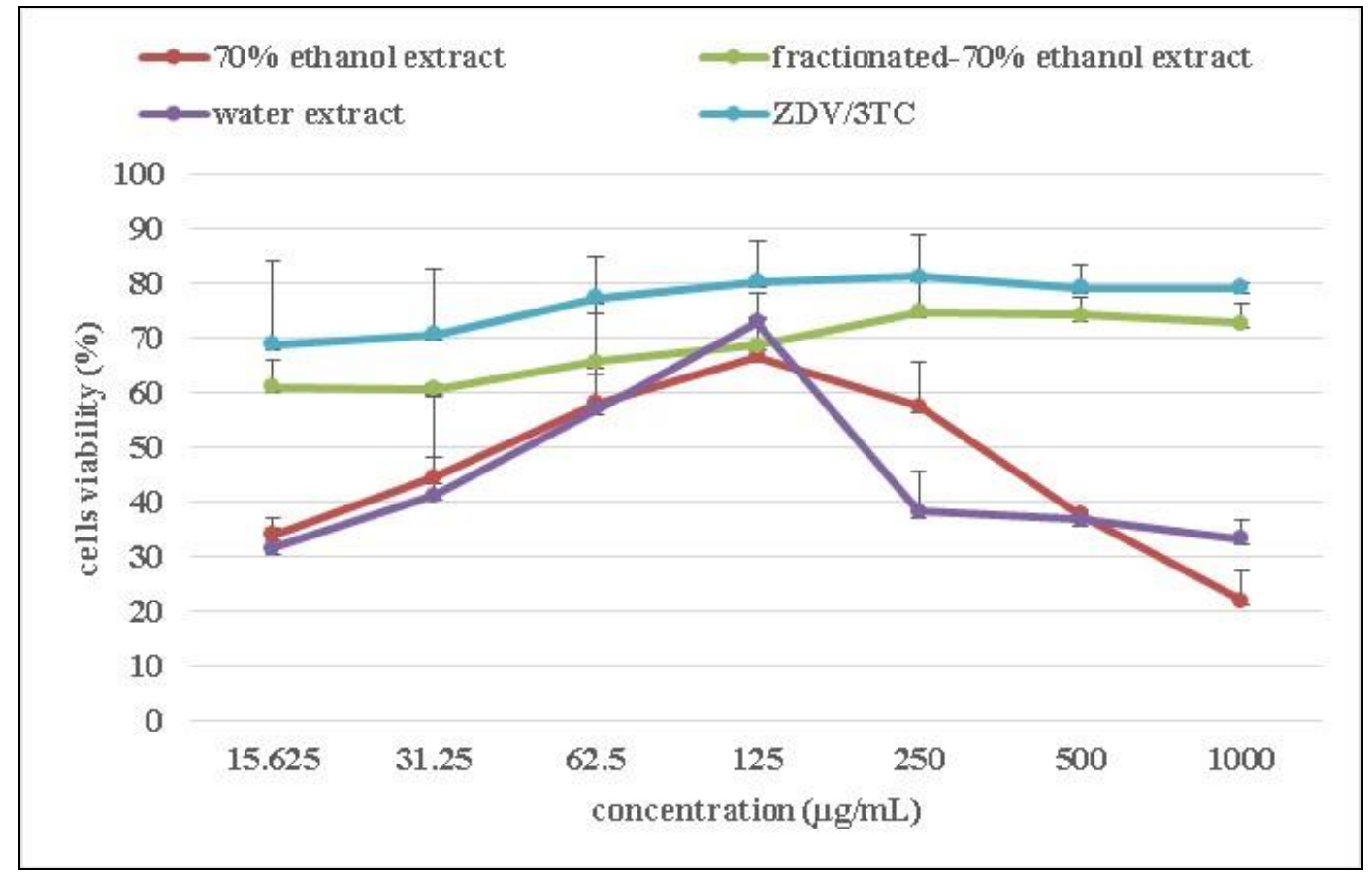

Figure 3: The Cytolysis inhibition effect of extracts of $J$. gendarussa leaves and ZDV/3TC on MT-4 cells viability were infected with HIV after 4 days incubation period.

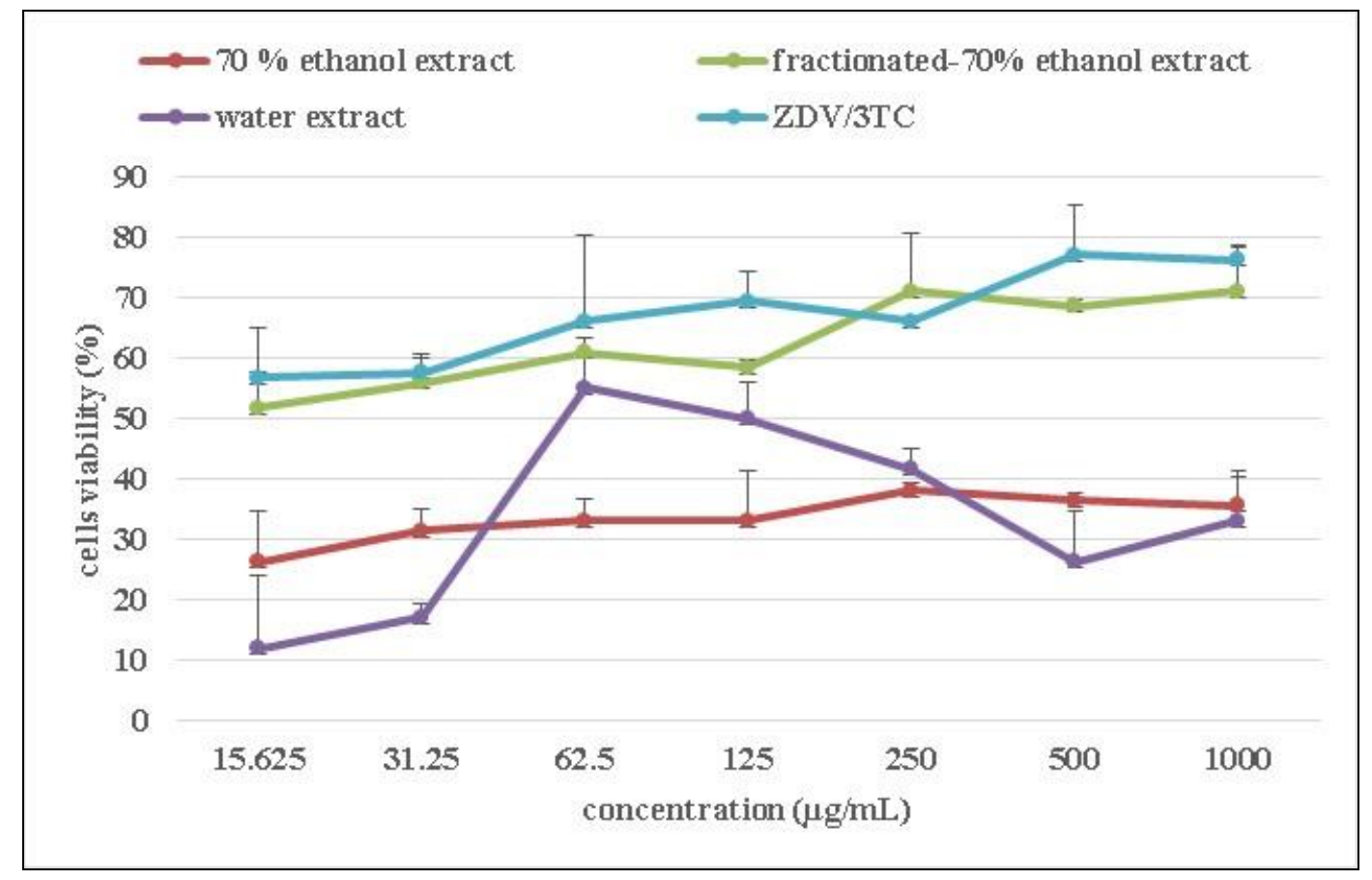

Figure 4: The Cytolysis inhibition effect of extracts of J. gendarussa leaves and ZDV/3TC on MT-4 cells viability were infected with HIV after 6 days incubation period.

From cytolysis inhibition test, it was found that incubation time affects the anti-HIV activity of $J$. gendarussa leaves extract on MT-4 cells (Figure 3 and Figure 4). Increasing of ethanol extract concentration of $J$. gendarussa could affect the viability of MT-4 cells infected with HIV. Then, the percentage of the MT-4 cells viability was used to determine the $50 \%$ effective concentration $\left(\mathrm{EC}_{50}\right)$ value of each test material. Probit regression analysis has calculated the $\mathrm{EC}_{50}$ value. The probit regression analysis was performed by using Minitab software. The $\mathrm{EC}_{50}$ value was presented in Table 2 . 
Table 2: $50 \%$ effective concentration $\left(\mathrm{EC}_{50}\right), 50 \%$ cytotoxicity concentration $\left(\mathrm{CC}_{50}\right)$, and Selectivity Index on $\mathrm{MT}-4$ cell cultures after 4 days and 6 days incubation period

\begin{tabular}{ccccccccc}
\hline & \multicolumn{2}{c}{$\mathbf{C C}_{\mathbf{5 0}}(\mu \mathrm{g} / \mathrm{mL})$} & & \multicolumn{2}{c}{$\mathbf{E C}_{\mathbf{5 0}}(\mu \mathrm{g} / \mathrm{mL})$} & & \multicolumn{2}{c}{ SI } \\
\cline { 2 - 3 } \cline { 7 - 8 } Time of Incubation & $\mathbf{4}$ days & $\mathbf{6}$ days & & $\mathbf{4}$ days & $\mathbf{6}$ days & & $\mathbf{4}$ days & 6 days \\
\hline EA & 1123.414 & 19.295 & & 29853.826 & 7289.706 & & 0.037 & 0.003 \\
FEA & 19211.001 & 354829.729 & & $3.045 \times 10^{-9}$ & 6.066 & & $6.309 \times 10^{12}$ & 58494.845 \\
WE & 2293.454 & 26.541 & & 187616.055 & 6861.831 & & 0.012 & 0.004 \\
ZDV/3TC & 67956.343 & 807290.794 & & $1.160 \times 10^{-14}$ & 1961 & & $5.858 \times 10^{18}$ & 411673.021 \\
\hline
\end{tabular}

EA: $70 \%$ ethanol extract of $J$. gendarussa leaves; FEA: fractionated-70\% ethanol extract of $J$. gendarussa leaves; WE: Water extract of $J$. gendarussa leaves; ZDV/3TC: Zidovudine-Lamivudine; SI: Selectivity Index $=\mathrm{CC}_{50} / \mathrm{EC}_{50}$.

Molecular docking test results (Table 3), it was presented the same chemical bonds among the amino acids of HIV-1 reverse transcriptase (3V4I) with flavonoids and alkaloids of J. gendarussa leaves and Zidovudine.

Table 3: Rerank score and hydrogen bonding interactions between receptors of HIV-1 reverse transcriptase (3V4I) with chemical compounds of $J$. gendarussa leaves

\begin{tabular}{cccccc}
\hline \multirow{2}{*}{ Class } & Chemical Compound & \multicolumn{3}{c}{ Amino Acid } & \multicolumn{2}{c}{ Rerank Score } \\
\cline { 3 - 5 } NRTIs & Zidovudine & Tyr 115 & Asp 113 & Lys 65 & \\
\hline & 2_(2_Amino_benzylamino)_methyl_benzyl alcohol & - & + & - & -71.1579 \\
& 2_(2_Amino_benzylamino)_O_methyl_benzyl alcohol & - & - & - & -71.9826 \\
Alkaloid & 2_Amino_O_methyl_benzyl alcohol & - & + & - & -52.3556 \\
& 2_Aminobenzyl alcohol & - & - & - & -48.7308 \\
& Justidrusamide AB & - & - & - & -82.4664 \\
& Justidrusamide CD & + & - & - & -84.0718 \\
\hline \multirow{5}{*}{ Flavonoid } & Gendarusin A & + & - & - & -94.7381 \\
& Gendarusin B & + & + & - & -83.6573 \\
& Gendarusin C & + & - & + & -106.808 \\
& Gendarusin D & - & - & - & -91.3127 \\
\hline
\end{tabular}

NRTIs: nucleoside reverse transcriptase inhibitors

\section{Discussion}

Cytotoxicity testing with incubation time variation was performed to determine the effect of incubation time against the cytotoxicity potential of $J$. gendarussa leaves extract on MT-4 cells. Cytotoxicity testing was performed by a colorimetric method using a WST-1 test. The test was based on the reduction of the WST-1 by live cells produce soluble formazan (Rode, 2008). The amount of formed formazan represents high cell viability, which is the numbers of active living cells metabolize WST-1 (Rampersad, 2012).

Observation of cytotoxicity activity was performed by calculating the percentage of MT-4 cells viability. Then a regression equation between the percentage of cell viability and the logarithm of concentration was determined. The $\mathrm{CC}_{50}$ value determined the amount of cytotoxicity activity of the extract. The $\mathrm{CC}_{50}$ value of an extract is the extract concentration of that able to decrease $50 \%$ of cell viability. In this study, cytotoxicity activity was observed on different days, namely on the fourth day and sixth day, because previous studies reported that incubation time differences caused a significant difference in $\mathrm{CC}_{50}$ values (Kimura et al., 1999). From this study, there were differences of $\mathrm{CC}_{50}$ value between the fourth and the sixth day, especially for the $70 \%$ ethanol extract and water extract of J. gendarussa leaves where the $\mathrm{CC}_{50}$ was not toxic at the fourth day and then become more toxic in the sixth day. It is apparently due to the compound content of the extract. The presence of alkaloid compounds seems to give a major influence on cell death when it's compared to the flavonoid compounds (Astuti et al., 2006). The influence of alkaloids against cell death could be identified from the results of $70 \%$ ethanol extract and water extract of $J$. gendarussa leaves (Figure 2), where on the sixth day of incubation almost of all concentrations causes the MT-4 cell viability less than 50\%. Meanwhile, the results of fractionated-70\% ethanol extract (free alkaloids) show the cell viability greater than $70 \%$ after 6 days incubation period.

In the anti-HIV activity test, we used inhibitors of cytolysis effect of $70 \%$ ethanol, fractionated-70\% ethanol extract and water extract of leaves J. gendarussa against MT-4 cell cultures infected with HIV after 4 days and 6 days incubation period as a parameter of anti-HIV activity. The results of the previous study stated that incubation of MT-4 cells with MOLT-4 / HTLV-IIIB (strains of HIV-1) for 4 days led to more than $95 \%$ cells contain viral antigen (Yang et al., 1996). Also, the incubation time difference caused a significant difference in $\mathrm{EC}_{50}$ and $\mathrm{CC}_{50}$ values (Kimura et al., 1999). Hence, 4 days and 6 days incubation period were chosen in this research.

This study found that $70 \%$ ethanol extract, fractionated-70\% ethanol extract and water extract of $J$. gendarussa leaves have an activity of cytolysis effect inhibiting on the MT4 cell with infected by HIV both at fourth day and sixth day incubation period. The $\mathrm{EC}_{50}$ value of a test sample represents the concentration of the test sample which can inhibit $50 \%$ of viral replication in a cell-based testing. An extract is said to have anti-HIV activity when the 
extract has $\mathrm{EC}_{50}$ below $100 \mu \mathrm{g} / \mathrm{mL}$ (Cos et al., 2006). From the $\mathrm{EC}_{50}$ values, the fractionate-70\% ethanol extract of $J$. gendarussa leaves has anti-HIV activity by inhibiting the cytolysis effect on HIV-infected MT-4 cells with an EC 50 value below $100 \mu \mathrm{g} / \mathrm{mL}$. Meanwhile, $70 \%$ ethanol extract and water extract of J. gendarussa leaves has lower anti-HIV activity since their $\mathrm{EC}_{50}$ value is greater than $100 \mu \mathrm{g} / \mathrm{mL}$.

The $\mathrm{CC}_{50}$ and $\mathrm{EC}_{50}$ values could be used to determine the Selectivity Index (SI) of anti-HIV activity of $J$. gendarussa leaves extract. The SI is used as a parameter which indicates toxicity of $J$. gendarussa leaves extract to cell and virus. The CC50 value should be greater than $\mathrm{EC}_{50}$ value. It was found that SI of fractionated-70\% ethanol extract much higher than the $70 \%$ ethanol extract and water extract of $J$. gendarussa leaves. The greater SI, the greater potential of a test material as a drug (Kimura et al., 1999; Volberding, 2008).

Molecular docking test results (Table 3) indicate that flavonoid compounds in J. gendarussa leaves and Zidovudine bind same amino acids. The rerank score of the flavonoid and Zidovudine are low. The rerank score of a compound represents its bond energy. Hence, the rerank score is used to predict the flavonoid and Zidovudine activity. Bond energy is the energy required for ligand binding to its receptor. The smaller the binding energy, more stable and easier a ligand binds its receptor will be. The more stable a ligand is binding a receptor, it could be predicted that the greater its activity will be higher (Thomsen and Christensen, 2006). The results of this research showed that fractionated-70\% ethanol extract of J. gendarussa has potential as an anti-HIV. In future, J. gendarussa could be used as a potential candidate for an anti-HIV drug.

Conflict of Interest: The authors declare that there are no conflicts of interest.

\section{Acknowledgement}

The authors would like to thank the Collaborative Research Center for Emerging and Reemerging Infectious Disease (CRC-ERID), Institute of Tropical Disease (ITD), Airlangga University for supporting Biosafety Level-3 facility, and Prof. Dr. Siswandono, Apt., MS. From Faculty of Pharmacy, Airlangga University who has a license of the Molegro software.

\section{References}

1. Astuti, E., Pranowo, D. and Puspitasari, S. D. (2006). Cytotoxicity of Phaleria macrocarpa (Scheff.) Boerl. Fruit Meat And Seed Ethanol Extract to Mononuclear Perifer Normal Cell Of Human Body. Indonesian Journal of Chemistry, 6(2): 212-218.

2. Chakravarty, A. K., Dastidar, P. P. G. and Pakrashi, S. C. (1982). Simple Aromatic Amines from Justicia gendarussa. 13C NMR Spectra of the Bases and Their Analogues. Tetrahedron. Elsevier, 38(12): 1797-1802.

3. Cos, P., Vlietinck, A., Berghe, DV., and Maes, L. (2006). Anti-infective Potential of Natural Products: How to Develop a Stronger in vitro "proof-of-concept". Journal of Ethnopharmacology. Elsevier, 106(3): 290-302.

4. Indonesia, D. K. R. (2008). Farmakope Herbal Indonesia, Edisi I (in Indonesian). Jakarta: Departemen Kesehatan RI, : 78-80.

5. Kangro, H. O. and Mahy, B. W. J. (1996). Virology Methods Manual. Academic Press, pp. $293-308$.

6. Kimura, E., Koike, T. and Inouye, Y. (1999). Macrocyclic Polyamines and Their Metal Complexes: A Novel Type of Anti-HIV Agent. Perspective on Bioinorganic Chemistry, 4: 145-164.

7. Kiren, Y., Deguchi, J., Hirasawa, Y., Morita, H., and Prajogo, B. (2014). Justidrusamides A-D, New 2aminobenzyl Alcohol Derivatives from Justicia gendarussa. Journal of Natural Medicines. Springer, 68(4): 754758.

8. Ko, Y-J., Oh, H-J., Ahn, H-M., Kang, H-J., Kim, J-H., and Ko, YH. (2009). Flavonoids as Potential Inhibitors of Retroviral Enzymes. Journal of the Korean Society for Applied Biological Chemistry. Springer, 52(4): $321-326$.

9. Luma H.N., Doualla M.S., Choukem S.P., Temfack E., Ashuntantang G., Joko1 H.A., and Shiro S.K. (2012). Adverse drug reactions of Highly Active Antiretroviral Therapy (HAART) in HIV-infected patients at the General Hospital, Douala, Cameroon: a cross-sectional study. Pan African Medical Journal. African Field Epidemiology Network, 12(1): 1-7.

10. Naif H. M., (2013). Pathogenesis of HIV infection. Infectious Disease Reports 2013. PAGEPress Publications, 5(Suppl 1), p. e6. doi: 10.4081/idr.2013.s1.e6.

11. Organization, W. H. (1989). In vitro screening of traditional medicines for anti-HIV activity: Memorandum from a WHO meeting. Bull World Health Organ, 87: 613-618.

12. Pattman R., Snow M., Handy P., Sankar K. N., and Elawad B. (2005). Oxford Handbook of Genitourinary Medicine, HIV, and Aids, 1st Edition. Oxford University Press, pp. 346-359.

13. Prajogo, B. (2014). Autentik Tanaman Justicia gendarussa Burm.f. Sebagai Bahan Baku Obat Kontrasepsi Pria (in Indonesian). Surabaya: Airlangga University Press.

14. Prajogo, B., Guliet, D., Queiroz, F, Wolfernder, J-L., Cholies, N., Aucky, H., and Hostettmann, K. (2009). Isolation of Male Antifertility Compound in n-Butanol Fraction of Justicia gendarussa Burm.f. Leaves. Folia Medica Indonesiana, 45(1): 28-31.

15. Prajogo, B., Widiyanti, P. and Riza, H. (2016). Effect Of Free Alkaloid And Non-Free Alkaloid Ethanol $70 \%$ Extract of Justicia gendarussa Burm.f.. Leaves Against Reverse Transcriptase HIV Enzyme In Vitro And Chemical Compound Analysis. Indonesian Journal of Tropical and Infectious Disease, 6(1): 1-4. 
16. Rampersad, S. N. (2012). Multiple applications of Alamar Blue as an indicator of metabolic function and cellular health in cell viability bioassays. Sensors. Molecular Diversity Preservation International, 12(9): 12347-12360.

17. Rode, H. J. (2008). Apoptosis, Cytotoxicity and Cell Proliferation. Roche Diagnostics GmbH, 4: 116-135.

18. Suryowinoto, M. and Pudjoarinto, A. (1985). Laporan Perjalanan ke Jayapura Sentani (Irian Jaya) (in Indonesian). Fakultas Biologi UGM. Yogyakarta, p. 19.

19. Thomsen, R. and Christensen, M. H. (2006). MolDock: A New Technique for High-Accuracy Molecular Docking. Journal of medicinal chemistry. ACS Publications, 49(11): 3315-3321.

20. Veljkovic, V., Mouscadet, J-F., Veljkovic, N., Glisic, S., and Debyser, Z. (2007). Simple Criterion for Selection of Flavonoid Compounds With Anti-HIV Activity. Bioorganic and Medicinal Chemistry Letters. Elsevier, 17(5): 1226-1232.

21. Volberding, P. (2008). Global HIV/AIDS Medicine. Elsevier Health Sciences, pp. 595-601.

22. Widiyanti, P., Prajogo, B. and Hikmawati, N. P. E. (2016). Cytotoxicity of Justicia gendarussa Burm.f. Leaf Extracts on MOLT-4 Cell. Indonesian Journal of Tropical and Infectious Disease, 6(1): 24-28.

23. Woradulayapinij W., Soonthornchareonnon N., and Wiwat C. (2005). In vitro HIV Type 1 Reverse Transcriptase Inhibitory Activity of Thai Medicinal Plants and Canna indica L. rhizomes, Journal of Ethnopharmacology. Elsevier, 101(1): 84-89.

24. Yang, D-W., Ohta, Y., Yamaguchi, S., Tsukada, Y., Haraguchi, Y., Hoshino, H., Amagai, H., and Kobayashi, I. (1996). Sulfated Colominic Acid: An Antiviral Agent That Inhibits The Human Immunodeficiency Virus Type 1 In Vitro. Antiviral Research. Elsevier, 31(1-2): 95-104.

25. Zhang, X., Yang, LM., Liu, GM., Liu, YJ., Zheng, CB., Lv, YJ., Li, HZ., and Zheng, YT. (2012). Potent AntiHIV Activities and Mechanism of Action of a Pine Cone Extract from Pinus yunnanensis.Molecules. Molecular Diversity Preservation International, 17(6): 6916-6929. 